\title{
NECESSITY AND LIMITS OF STATE INTERVENTION TO THE ECONOMY OF MODERN COUNTRIES
}

\section{Muzychenko G. V.}

\section{INTRODUCTION}

The financial crisis of 2008-2009 has demonstrated the lack of theoretical research on the state as a public goods and services producer and on the optimal scale of state intervention to the institutional structure of the national economic system as well. The ability of market relations subjects to adapt to new conditions of economic instability, the state's ability to form an effective mechanism to compensate for the global economic crises impact on national economic systems by evaluation the country's resource potential necessary for achievement of the set goals, taking into account available budget possibilities and emerging budget constraints depend on solving these fundamental theoretical problems directly.

The dominant scientific paradigm of the interpretation of the essence of the interaction of the state and the market, based on neoclassical approaches and views of other economical schools' representatives according to which the state is devoted to increase the level of market efficiency by eliminating its "failures», proved to be imperfect due to the inability to explain modern institutional transformations ${ }^{1}$.

The globalization processes' strengthening has substantially changed the understanding of the public finances essence and led to the evolution of theoretical approaches to their interpretation. The traditional public finance theory based on the welfare and public choice focuses on the formation of the revenue and expenditure part of the central (state) and local budgets, examines the mechanism of their interaction in the context of financing public goods and services. A new theory of public finance considers the interaction of the state and the market in the context of cooperation and competition between public and private market agents regarding the provision of public services and takes into account the need for concerted action of governments at the national and international levels to address global development challenges, especially in the face of aggravation of the crisis phenomena in the economy.

As A.G. Zeldner pointed: "We can endlessly argue about the state's place and role in the economy, but there is a period in the development of each

${ }^{1}$ Koliada, T. Forming of budgetary strategy of Ukraine: theory, methodology, practice. Irpin: University of State Fiscal Service of Ukraine, 2016. 396 p. 
country when only the activation of the role of the state and the clear longterm strategy development can provide a steady socio-economic growth» ${ }^{2}$.

Under conditions of globalization, when the economy goes beyond the bounds of the state, the problem of interdependence between the state and the economy becomes of particular importance for economic methodology. Economic determinism' followers associate this process with the dismantling of state institutions in general, with the self-liquidation of the state as such. Instead, A. S. Galchinsky believes that this problem is associated with a profound systemic reconstruction of state functions, which are due to the controversial process of becoming a post-industrial, global society ${ }^{3}$.

We are agree with Galchinsky's opinion that the modern global information economy, which operates on-line, is based on a fundamentally different basis. A new understanding of the need for a systemic separation of political power and economy is going to change the previous Keynesian and Neo-Keynesian approaches based on the state's functions expansion. It is about the limiting of state's economic function and developing new mechanisms for economy regulation, which will be formed within the economy itself.

The level of state interference in the country's economy is determined by the share of GDP redistributed through the budget. Today there is no consensus among scholars regarding the determination of the optimum budget size and its structure. The analysis of scientific sources shows that a significant part of the key issues in determining the optimal size of budget expenditures for a given country with all its internal and external factors remain unresolved. Therefore, every year during the process of Ukraine's fiscal policy main directions defining for the relevant year, scholars and experts discuss the main parameter of fiscal policy - the share of GDP redistribution through the consolidated budget.

\section{Theoretical aspects of state intervention to the economy}

After the declaration of independence and sovereignty of Ukraine as a state, the political power's division and formation is conducted in accordance with a democratic regime characterized by the following features: public sovereignty, political pluralism, consensual type of political culture, legal guarantees of political, civil and cultural freedoms. Democracy has its own influence on the economic system as reflected in the efforts of most democratic states to build a social model of the state.

2 Zeldner, A. State and market: strategy of development of economic relations. Announcer of Institute of economy of Russian Academy of Sciences, 2007. Vol. 3, p. 10.

${ }^{3}$ Гальчинський А. Вилікувати економіку можна тільки на ліберальних засадах. URL: http://www.dt.ua/2000/2020/68567/ (Accessed 15.09.2019). 
The transformation of our state's social structure in the 1990's sets an agenda a tusk for choosing a model of social policy and the formation of qualitatively new social institutions. However, so far, social policy in Ukraine is actually built on the principle of "proper response», the situational distribution of financial and organizational resources, which provide for the «removal» of the most acute social problems that may be the cause of social discontent as it is observed in most countries of the world, and therefore, can become a real threat to political stability and the whole Ukrainian society democratization course.

There are a lot of foreign literature on the analysis of social policy's models functioning in the modern democratic world countries. Such scholars as J. Buchanan, G. Epsing-Andersen, N. Furniss and T. Tilton, V. Georges and P. Wilding, R. Mishra, R. Titmuss, F. Fukuyama, etc. are of particular interest for this topic. An important basis for analyzing the problems identified in the article is the Ukrainian and Russian scholars' research where they study the state's social functions transformation problems in the democracy and globalization conditions in post-Soviet countries. They are N. Volgin, V. Gordin, V. Goshovska, A. Kolot, E. Lianov, V. Lublin, A. Krentosaska, M. Carlin and others.

However, today there is no unity among scientists in the understanding of social policy functional mechanisms regarding the objective needs' realization Ukrainian society socio-economic development. It is particularly traceable in the post-crisis economy, where there is no correlation between political and economic research, which leads to discrepancies between the Ukrainian state's political statements declaration and their real possibilities to provide.

Turning to the history of the «social state» concept's emergence it should be noted that for the first time this term was officially used in the 1949 in the Constitution of the Federal Republic of Germany and, literally, only afterwards entered into a broad scientific circle. The works of G. Ritter (Germany), K. Sole (Spain), A. Brown (USA), M. Bonetti (France) were devoted to the enlightenment of social state theoretical foundations. The «social state» concept in its content is broader than the «rightful state» concept, because it reflects not only the social freedom's degree, but also the social justice one. The social state's essence is to promote the formation of such modern society's elements as social market economy, social democracy, social ethics ${ }^{4}$.

Thus, the social market economy provides for the creation of favorable conditions for the all population's segments inclusion to the market mechanism at the microeconomic level, as well as the minimum wage

${ }^{4}$ Muzychenko G., Koliada T. Evaluation of State Intervention to the Country Economy by Global Democratic Markers. Scientific Development and Achievements. London. 2018. P. 426. 
establishment is not lower than the level of the cost of living, granting of subsidies to low-income categories of the population, the all types of social insurance development and social partnership's mechanism security.

In turn, social democracy reveals the content of various types (territorial, industrial, professional) self-government and its organic connection with the rightful state.

It should be emphasized that both the ideological process in society and the definition of role that state gives to the ideologies extension are an important features for national political regime. On our opinion, the symbiosis of at least two major political ideologies - social democratic and liberal prevails now in Ukraine. The final national ideology's determination process is still ongoing in the country, and the country's socio-economic development level plays one of the main role in it.

Thus, the social-democratic ideology based on E. Bernstein's ideas prefers state regulation of the economy and recognizes the private property economic efficiency, as well as advocates for maintaining social equilibrium by increasing budget expenders on the social sphere.

With regard to liberal ideology, it has gone through a difficult path in its evolutionary development, and now it is possible to distinguish the following approaches: classical liberalism, social liberalism, neoliberalism, liberalism. Thus, classical liberalism advocates such ideas as the absolute human value, his rights and freedoms, the rule of law and civil society, the state's non-interference in the economic and social spheres, the free market and cosmopolitanism. Social liberalism is based on J. Keynes's ideas and understands the state as an institution of universal welfare and prosperity. This approach is close to European Social Democracy in its content. In turn, neoliberalism is based on M. Friedman and F. Hayek's research. Representatives of this area criticize the state regulation of the economy as an ineffective economic, that generates disorder and corruption, defends the full privatization and market's self-regulators ideas ${ }^{5}$.

There are three established scientific and legal constructions: German model of the social and legal state (conservative-corporatists model), the Swedish model (social-democratic model) and the American model (liberal model).

According to G. Esping-Andersen's classification, modern states have proposed three possible types of reaction to global change. In the SocialDemocratic Social States (Sweden), attempts were made to maintain loyalty to the welfare policy through the jobs' creation in the public sector. The governments of these countries are trying to make an attempt to adapt the

${ }^{5}$ Масгрейв Ричард А., Масгрейв Пегги Б. Государственные финансы: теория $u$ практика. М.: Бизнес Атлас, 2009. С. 128-129. 
social state's basic directions to the changing economic characteristics of the economy management in the socio-economic globalization's context.

However, today there are increasing doubts about the viability of swedish way for solving the social state's classical principles and activity methods' adaptation problem in the modern conditions on a long-term basis.

As for the liberal model of a social state, which currently operates in the USA, the state deregulation idea is actively being implemented there.

A conservative-corporatist approach can be the third model's example that was implemented in Germany, where working places in non-productive sectors were eliminated and, in fact, the increasing unemployment strategy was chosen, in which funds are used to invest in high-performing industries and enterprises ${ }^{6}$.

As we see, the social state activity models vary not only in form but also in understanding both the mechanisms of the state of welfare ensuring and the social state developing ways a in the face of radical changes in the world political, economic, social and legal space.

Despite all of these models' differences, certain common features that reveal the social assistance essence provided by the state can be distinguished. In particular, assistance is provided if the income received is lower than the officially recognized poverty line or assets are below a certain minimum. In addition, it is intended to cover the difference between the poverty line and the real income for all who need help.

The state of welfare formation is proved to be a significant social achievement of the world civilization in the 20th century. It became a significant factor contributing to solving the economic development contradictions in the conditions of the NTR, stimulating factors of growth, productivity and innovation, and in political terms ensured social stability, contributed to the justice and solidarity principles consolidation. The age of the social state actually redirected the civilization vector, accompanied by attempts to revise the socio-economic growth principles and the state's role, changing the national income redistribution nature.

However, society does not stand in one place, but it constantly develops under the pressure of many factors, both political and economic, which necessitate the policy update. Social policy modernization is a natural and necessary process due to the economy and social structure transformation. Russian researcher V. V. Lublin pointed that in the 1970's the West's development long-term cycle connected with the social state's mechanisms formation had come to the end. However, in the time following, the previous

${ }^{6}$ Koliada T., Muzychenko G. Transformation of the role of state in economy of Ukraine from the respective of Euro-integration process. European integration processes in the $21^{\text {st }}$ century: key trends, major challenges and new opportunities. 2018. Kyiv: Ukrainian Association of Teachers and Researchers for European Integration, pp. 276-287. 
economic development conditions had undergone significant changes, which led to the beginning of a new social state's development stage, whose boundaries are largely determined by both the world economic processes' transformation and the modern countries political and ideological development's course ${ }^{7}$.

According to the Western researchers' position, the main problem now is that the state loses the ability to control the process of capital transfer. The industrially advanced countries' governments, which tried to combat unemployment, had to make a concerted turn to the "supply-side policy». The goal was to set a minimum level of return for productive investment above that provided in international markets. One of the main points in this scheme is that it is becoming increasingly difficult to finance «big social policy», since the necessary borrowing in the new environment becomes more costly compared to the previous period when governments were more likely to attract additional resources. From certain time, these changes began to form the strategy's boundaries aimed at changing the state's role and functions in the economy and social development.

Such a policy is aimed at transforming the model, based on the new context of interaction between different industry and corporate interests, social partners and social groups. One of the key aspects is the change in the balance between factors of production (capital and labor), which is reflected in the entrepreneurs' position strengthening at the society level and the main state's efforts are aimed at increasing the competition policy effectiveness.

Therefore, now Ukraine faces a choice which role the state should play in the economic processes' regulation in the country and depending on the solution to this question, which ideology it should prevail in the public life development. However, it should be emphasized that in Ukraine, as a democratic state, at the Constitution level has established that the social life is based on the political, economic and ideological diversity principles (Part 1, Article 15). This means that no ideology can be recognized by the state as obligatory: the Ukrainian state creates different conditions for the different ideologies development, except, of course, an ideology that is anti-state in its content and essence ${ }^{8}$.

Excessive state interference in redistributive processes, equalization of income through social transfers leads to a decrease in business activity in society and a reduction in the production efficiency in general. On the other

${ }^{7}$ Коляда Т. А. Фінансове забезпечення соціальних функцій держави в умовах посткризової трансформації соціально-економічної системи. Наукові записки. Серія «економіка»: збірник наукових праџь Наџіонального університету «Острозька академія», 2012. Вип. 20. С. 84.

${ }^{8}$ Muzychenko G., Koliada T., Churkina I. Impact of European Integration Process on the Necessity of Long-Term Budget Planning Introduction in Ukraine. Baltic Journal of Economic Studies, 2017, no.3 (5), pp. 330. 
hand, the state's role reducing in regulating household incomes leads to an increase in income differentiation, social tension, social conflicts' aggravation and, as a result, drop in production, lowering its efficiency. The achievement of the state interference optimal scale in the social relations' regulation in society is associated with the resolution of the contradiction between efficiency and social justice.

Thus, the state's social policy in a market economy should be a very subtle tool. On the one hand, it is intended to promote social stability and mitigate social tensions, and on the other hand, in no way undermine the entrepreneurship's stimulus-reaction and highly effective employment.

\section{Ukraine in the context of European standards of state regulation of economic development}

Global economy changes have forced the scientific community to return to basic questions about the state: what should be its role, task, function, because the sustainable development - both economic and social - is impossible without an effective state. The lack of an adequate theoretical basis for interpreting the state's role and its functions in national economies negatively affected the prospects of exit from the structural and financial crisis ${ }^{9}$.

In the current multifaceted, mixed market economy, the state plays an active role in shaping the most important processes of socio-economic development. The public sector has a dominant position in the economy due to using resources to finance state-guaranteed public services and various income redistribution programs. The public sector also plays an important role in the financial markets of most countries, owing to significant amounts of its borrowing from the private sector and a substantial amount of its assets in the economy. The public services financing and the income redistribution in most countries of the Organization for Economic Cooperation and Development (OECD) exceeds $40 \%$ of GDP, and in some countries it even approaches $50 \%$ of $\mathrm{GDP}^{10}$. The state's influence magnitude is particularly increasing in the period of aggravation of the economic and social situation in the country. In periods of stable development and absence of crises, the scale of government influence is shrinking and the state, like other market agents, operates within defined long-term programs and strategies.

The level of state interference in the country's economy is determined by the share of GDP redistributed through the budget. Today there is no consensus among scholars regarding the determination of the optimum budget

${ }^{9}$ Масгрейв Ричард А., Масгрейв Пегги Б. Государственные финансы: теория $u$ практика. М.: Бизнес Атлас, 2009. С. 112.

${ }^{10}$ Muzychenko G., Koliada T. Evaluation of State Intervention to the Country Economy by Global Democratic Markers. Scientific Development and Achievements. London, 2018, pp. 431-432. 
size and its structure. The scientific sources analysis shows that a significant part of the key issues in determining the optimal size of budget expenditures for a given country with all its internal and external factors remain unresolved. Therefore, every year during the process of Ukraine's fiscal policy main directions defining for the relevant year, scholars and experts discuss the main fiscal policy parameter - the share of GDP redistribution through the consolidated budget.

The famous American scientist Richard Masgrave noted: «More than 20 percent of the gross national product (GNP) in the USA is consumed by the government today. Total state expenditures, including transfers, forming to 35 percent of GNP, and tax revenues - more than 30 percent of GNP. Despite this, the state participation in the US economy in comparison with other developed countries is not so significant. For example, in Western Europe, more than half of economic activity is in the public sector. In addition to budget functions, state policy influences the course of economic activity through monetary, power and other mechanisms» ${ }^{11}$.

Budget and GDP ratio - an important economic problem, due to the particular state economy model functioning' peculiarities. Ukraine has been showing a tendency to increase the consolidated budget expenditures in recent years. By itself, this fact is not threatening because the average government spending in developed countries has a wide range of differences - from 30 to $60 \%$ of GDP, which does not prevent a sufficiently high level of well-being of the population. However, in Ukraine, as in most emerging market countries, there are certain peculiarities in socio-economic development, which requires scientific substantiation and determination of economic expediency in relation to increase of budget expenditures.

The growth of the state's role in the income redistribution is inherent in all European countries. Their common feature is a significant share of public expenditure in GDP. It can be argued that in most countries with a developed market economy, the indicators characterizing the budgetary burden are comparable. Due to the integration of economic, financial, currency, and credit systems in European countries, the convergence process has taken place equalizing the value of financial and budgetary indicators, in particular, the budget deficit, public debt, inflation, interest rates, etc. Among the main benefits of such integration is the coordinated, even development of all EU Member States. The disadvantage of such an association is the particular country government inability to accelerate its own economy development.

Based on the analysis of only the above indicators, it can be noted that the state's role in the Ukrainian economy is rather high. Thus, in 2017 the share of state expenditures with the Pension Fund in GDP in our country was

${ }^{11}$ Масгрейв Ричард А., Масгрейв Пегги Б. Государственные финансы: теория $и$ практика. М.: Бизнес Атлас, 2009. С. 17. 
42.5\%. Unfortunately, the state's economic regulating mechanism capacity remains unsatisfactory and requires immediate reform.

The prominent American economist, winner of the Nobel Prize for Economics (1970) Paul Samuelson noted: «Democracy generates a state that is desirable to it. Unfortunately, the history will answer two questions - is the extension of the state's powers good or bad policy, and whether it should receive approval from all who are sincerely interested in preserving and improving the positive aspects of our system - after a long time only. In politics, as in any other area, it is true that the road to Hell is paved with good intentions» ${ }^{12}$.

In order to ensure the economy's growth, Ukraine has actually exhausted all possibilities to expand the range of state functions in terms of their budget financing. Thus, some scholars believe that for our country the optimum or reverse of the state consumption volume is $25-27 \%$ of GDP, while others define it at the level of 32-33\% of GDP (excluding social transfers). A further public spending increasing is already threatening the country's development. Especially during the world economy recession, which occurs in modern conditions, it is necessary to reduce budget expenditures.

In this regard, the present condition and the near-term outlook of the budgetary burden on the Ukrainian economy are of particular interest. It must be agreed with the many experts' opinion that when calculating the budget burden indicator, it should been taken into account not only the Consolidated Budget revenues, but the extrabudgetary funds as well (Table 1).

Table 1

Budget burden in EU-28 countries and Ukraine, \% of GDP

\begin{tabular}{|l|c|c|c|c|c|c|c|c|}
\hline \multicolumn{1}{|c|}{ Indicators } & $\mathbf{2 0 1 0}$ & $\mathbf{2 0 1 1}$ & $\mathbf{2 0 1 2}$ & $\mathbf{2 0 1 3}$ & $\mathbf{2 0 1 4}$ & $\mathbf{2 0 1 5}$ & $\mathbf{2 0 1 6}$ & $\mathbf{2 0 1 7}$ \\
\hline EU-28 countries & 50,0 & 48,6 & 49,0 & 48,6 & 48,2 & 47,4 & 47,2 & 46,9 \\
\hline Ukraine & 45,9 & 42,7 & 46,1 & 46,3 & 44,6 & 45,0 & 45,8 & 45,2 \\
\hline
\end{tabular}

Source: compiled according to the statistics of the European Union (http://appsso.eurostat.ec.europa.eu) and the State Statistics Service of Ukraine (http://www.Ukrstat.org)

In order to compare the EU countries and Ukraine budget structure indicators correctly, the amount of deductions to extrabudgetary funds (pension and social), which were also reflected in the social benefits indicator, was added to the Ukrainian budget expenditures.

According to the data, the budgetary burden in Ukraine is slightly lower than in the EU zone's countries, but the domestic indicator is characterized by considerable volatility and the opposite trend direction for its

\footnotetext{
${ }^{12}$ Самуэльсон П. Экономика. Москва: МГП «Алгон» ВНИИСИ, 1992. Т. 1. С. 152.
} 
changes. If in European countries there is a tendency to decrease or stabilize the growth rates of budget expenditures, in Ukraine, their uneven gradual growth occurs.

Before consolidating the budget and looking for mechanisms for its implementation, it is necessary to clearly determine at the state level what the demand or supply economy the government is trying to build in the country, since it will depend on the choice of directions and volumes of budget funds spending.

Demand economy provides for significant state subsidies (including social transfers) from the budget to support aggregate demand in the country. In order to have a multiplier effect of spending budget funds, it is necessary to limit the volume of imports to the country and thereby stop the outflow of currency from the country. It will be problematically to do it in the context of Ukraine's accession to the WTO. In addition, in order to surmounting the crisis, it is necessary to direct budgetary funds for investments, not for consumption.

In Ukraine it is necessary to develop the economy of supply through the introduction of import substitution of technologies and increase of domestic goods and services' volumes. Such economy's model implies an increase in the public investment volume in innovative and infrastructure projects, which will lead to an increase in public debt, with the effect only tangible in the medium and long term.

The all leading countries' governments have faced with the impossibility of constantly stimulating demand in the context of the global economic recession. Due to restrictions on public investment, falling living standards, reducing the private investment volume and the unavailability of credit resources, the proposals to return production to the metropolis are increasingly being heard as one of the options for anti-crisis maneuver of states, which can reduce unemployment and create new jobs.

Actually, there is a question for the world about the transition to a new model for building economic relations - the economy of the proposal, which involves modernization as a basis - production, and its superstructure the nature of public relations. And the fiscal policy forms and reflects the type of state economic model.

Regarding the main economic development indicator - the GDP growth rate, there is no consensus among scientists on the budget expenditures impact on the rate of economic growth, because each country has its own optimum in the size of public expenditures. This indicator is affected by many factors, in particular, the structure of expenditures, the economic development cyclicality, the external markets situation, and the energy's cost for Ukraine as well. 
Scientists have proven that the multiplier of reduces budget expenditures by $1 \%$ leads to an average GDP drop of $1.7 \%$. According to IMF's experts calculations, the GDP rate is declined today within the range of $1.5-2 \%$ of GDP. In addition, the financial resources global redistribution mechanism calls into question the existence of a direct correlation between GDP growth rates in a particular country and the results of this growth. Therefore, forecasts are made that the economic development of countries in the present conditions should take place through fiscal consolidation, at least during the next 15 years. The growth of world GDP will be achieved by countries with growing consumption markets. Today in the world there are 20 fast-growing countries, for which markets must be fought, because now a new global system of economic growth is being created in the world ${ }^{13}$.

In this regard, J. Stiglitz warns that when the government cuts costs, there is a slowdown in economic growth, an increase in unemployment and a reduction in incomes, which leads to a reduction in tax revenues. The state budget eventually gain nothing or improve slightly. However, there is one way out from this difficult situation. Concerns about the amount of debt should lead to a change in the structure of public spending, to costs that bring high economic returns. But borrowing to finance investments (for example, in technology, infrastructure and education) with a profitability of 5 or $6 \%$ can lead to a reduction in long-term national debt, as growth, both in the short and long term, will bring more than enough additional tax revenues to pay interest rates ${ }^{14}$.

The current state expenditures reduction signals to financial market participants about the increasing of confidence in government actions in the long-term outlook by reducing the budget deficit, which in turn will contribute to an increase in aggregate demand in the country. On the other hand, the reduction of expenditure items of lower political significance, such as budget investments, will have a weaker effect on the degree of confidence in the proposed measures. Thus, when making managerial decisions regarding the budget expenditures reduction in order to balance the budget and reduce its deficit it is advisable to give priority to measures aimed at reducing current expenditure's items, since this will have a more positive effect on the economic development's pace than the public investment reduction.

The state must concentrate its limited resources on clearly defined basic functions. Budget policy should be based on the relative state participation effectiveness assessment in various economic activity's spheres and minimize

${ }^{13}$ Koliada T., Muzychenko G. Transformation of the role of state in economy of Ukraine from the respective of Euro-integration process. European integration processes in the $21^{\text {st }}$ century: key trends, major challenges and new opportunities. 2018. Kyiv: Ukrainian Association of Teachers and Researchers for European Integration, P. 284.

${ }^{14}$ Стиглиц Дж. Е. Крутое пике: Америка и новый экономический порядок после глобального кризисна. М. : Эксмо, 2011. С. 373. 
the budgetary resources distribution in areas where the state's participation is unnecessary or ineffective.

In the context of the globalization and the transparency of most economies in the world, when crises are of an all-embracing nature, and among the factors that trigger them the institutional ones become dominate, we must talk about the decisive role of the state in overcoming the crisis phenomena, the need for intervention in market mechanisms and the introduction of manual control of the situation. At the same time, it should be emphasized that the modern socio-economic structure of Ukraine, which was formed as the economy institutional transformation result, is characterized by the strengthening of the state's role as a public goods producer, as is the case for most European countries.

The governments of the countries that systematically undertake longterm budget forecasts have developed effective measures to ensure the state sustainable development through the pension systems' restructuring or the creation of special funds for future needs. Publicity and availability of information about long-term sustainable development trends is a prerequisite for obtaining public support and confidence from the government's efforts to reduce the long-term budgetary tension. There is a high probability that the government's previous measures to expand fiscal space are outdated due to the lack of transparency in obtaining information for forecasting and their inability to minimize political pressure for reform. But all countries that have already introduced budget strategic planning and benefited from its use are optimistic about their ability to effectively manage the public regulation of the economy until the next state of emergency in the budget sphere arises in the future.

\section{CONCLUSION}

During making managerial decisions in democratic societies it is necessary to find a compromise between the state and the population of the country - taxpayers and public services recipients, since the public good value is determined by the subjective and psychological assessments of its consumers. Lack of the state government trust on the part of the population may ignore the implementation of the proposed "rules of the game" by changing the taxpayer's jurisdiction, switching to shadow business practices, increasing consumer confidence in society, or even switching to open actions disobedience that will lead to the emergence threats to fiscal stability in the country.

Unfortunately, the change in the social way of life in Ukraine was not ensured by appropriate economy modernization and rethinking the nature of the relationship between the state and society over the volume of guaranteed public goods and services provision. The lack of an inventory of social privileges (benefits) that the state provides to its citizens allows certain citizens categories to use several of them simultaneously, which adversely 
affects the implementation of the budget system's fairness and impartiality principle and generates consumer sentiment in society.

In the context of fiscal consolidation and post-crisis economic recession, it is imperative to reduce the social benefits list and state support directions, which will increase those remaining benefits' financing and increase the public services' efficiency and quality. At the same time, the social benefits' total amount received by one person per month can not be higher than the subsistence minimum. It is necessary to legislatively fix restrictions on the maximum for the social assistance's amount per person. It is also necessary to determine clearly which categories of citizens need state social assistance and on what criteria such categories of population will be determined.

It is necessary to return to the ideology that a person should work to keep himself and his family safe if he has no restrictions on his health or for other reasons. The state is not obliged to give money to citizens, but only to create conditions for obtaining work. Therefore, the priority task is to prepare public opinion for the transition to a new model of relations with the state. Such an initiative should come not only from the state, it is necessary to involve public organizations and scientists to explain the irreversibility and the need for such transformations, to highlight the benefits that citizens of most democratic and market-rich countries of the world already have.

The reduction of current state expenditures signals to financial market participants about the increasing of confidence in government actions in the long-term outlook by reducing the budget deficit, which in turn will contribute to an increase in aggregate demand in the country. On the other hand, the reduction of expenditure items of lower political significance, such as budget investments, will have a weaker effect on the degree of confidence in the proposed measures. Thus, when making managerial decisions regarding the reduction of budget expenditures in order to balance the budget and reduce its deficit it is advisable to give priority to measures aimed at reducing current items of expenditure, since this will have a more positive effect on the pace of economic development than the reduction of public investment.

The state must concentrate its limited resources on clearly defined basic functions. Budget policy should be based on the assessment of the relative effectiveness of state participation in various spheres of economic activity and minimize the distribution of budgetary resources in areas where the participation of the state is unnecessary or ineffective.

In the context of the globalization and the transparency of most economies in the world, when crises are of an all-embracing nature, and among the factors that trigger them the institutional ones become dominate, we must talk about the decisive role of the state in overcoming the crisis phenomena, the need for intervention in market mechanisms and the 
introduction of manual control of the situation. At the same time, it should be emphasized that the modern socio-economic structure of Ukraine, which was formed as a result of the institutional transformation of the economy, is characterized by the strengthening of the role of the state as a producer of public goods, as is the case for most European countries.

\section{SUMMARY}

The article has a deal with the evaluation of the state intervention range to the economy of modern countries and Ukraine as well. It is pointed the new state social policy priorities, caused by changes in the social structure of society and the global shift in the market for factors of production (capital and labor) in the context of globalization.

The essence of the European integration processes' influence on the transformation of the state's role and tasks in regulating the economic situation in Ukraine is revealed. It is determined that the state as an institution acquired new qualities due to the growing interdependence of the state and the economy in the conditions of globalization. The objective and irreversible strengthening of the state role in overcoming the crisis phenomena in the economy, which is accompanied by a change in the nature of the national income redistribution and the budget and GDP ratio is proved.

It is substantiated the necessity of preparing public opinion for the transition to a new model of relations with the state, based on the domination of ideology that a person must work to keep himself and his family safe if he has no restrictions on health or for other reasons. The state only has to create conditions for work. The irreversibility and necessity of such transformations is confirmed by the experience of most of the democratic and market-driven countries of the world.

\section{REFERENCES}

1. Гальчинський А. Вилікувати економіку можна тільки на ліберальних засадах. URL: http://www.dt.ua/2000/2020/68567/

2. Гальчинський А. Tри кроки бюджетної політики. URL: http://www.dt.ua/publications/2006/09/15/241731/

3. Коляда Т. А. Формування бюджетної стратегї Украӥни: теорія, методологія, практика. Ірпінь : Університет ДФС України, 2016. $396 \mathrm{c}$.

4. Коляда Т. А. Фінансове забезпечення соціальних функцій держави в умовах посткризової трансформації соціально-економічної системи. Наукові записки. Серія «економіка»: збірник наукових праць Національного університету «Острозька академія», 2012. Вип. 20. C. 81-86. 
5. Масгрейв Ричард А., Масгрейв Пегги Б. Государственные финансы: теория и практика. М.: Бизнес Атлас, 2009. 716 с.

6. Музиченко Г. В. Вплив сучасних світових соціальноекономічних процесів на зміст соціальної політики держави. Науковий вісник. Одеський державний економічний університет. Всеукраӥнська асоціація молодих науковиів. Науки: економіка, політологія, історія. 2011. № 9 (134). С. 181-189.

7. Самуэльсон П. Экономика. Москва: МГП «Алгон» ВНИИСИ, 1992. T. $1.333 \mathrm{c}$.

8. Стиглиц Дж. Е. Крутое пике: Америка и новый экономический порядок после глобального кризисна. М. : Эксмо, 2011. $512 \mathrm{c.}$

9. Шахова Г. Я. Методологические особенности долгосрочного бюджетного планирования: мировой опыт. Финансовый журнал. 2009. № 2. C. 99-108.

10. Фінанси: Навч. посіб. К.: Знання, 2006. 415 с.

11. Koliada T., Muzychenko G. Transformation of the role of state in economy of Ukraine from the respective of Euro-integration process. European integration processes in the 21st century: key trends, major challenges and new opportunities. 2018. Kyiv: Ukrainian Association of Teachers and Researchers for European Integration, pp. 276-287.

12. Muzychenko G., Koliada T., Churkina I. Impact of European Integration Process on the Necessity of Long-Term Budget Planning Introduction in Ukraine. Baltic Journal of Economic Studies, 2017, no. 3 (5), pp. 329-333.

13. Muzychenko G., Koliada T. Evaluation of State Intervention to the Country Economy by Global Democratic Markers. Scientific Development and Achievements. - London, 2018, pp. 421-432.

14. Zeldner, A. State and market: strategy of development of economic relations. Announcer of Institute of economy of Russian Academy of Sciences, 2007. Vol. 3, p. 5-13.

\section{Information about the author: Muzychenko G. V.,} Doctor of Political Sciences, Professor at the Department of Political Sciences and Law, South Ukrainian National Pedagogical University named after K. D. Ushynsky 26, Starofrankivska str., Odessa, 65020, Ukraine 